\title{
The Effect of Transformational Leadership, Work Discipline, and Satisdaction on Lecturers' Performance at the Tarbiyah and Teaching Faculty of UIN Antasari Banjarmasin
}

\author{
Mauly Sihombing *, Wahyu, Sulaiman \\ Master Program of Education Management, Universitas Lambung Mangkurat, Banjarmasin 70123, \\ Indonesia
}

\section{Article history:}

Submission August 2020

Revised September 2020

Accepted September 2020

${ }^{*}$ Corresponding author:

E-mail:

molyoktavilisasihombing@gmail.com

\begin{abstract}
Lecturer performance is critical in determining the quality of education in higher education. The objective of the study is to analyze some variables that theoretically influence the lecturers' performance. Those variables are Transformational Leadership, Work Discipline, and Job Satisfaction. This study was conducted at the Faculty of Tarbiyah and Teacher Training of Antasari UIN Banjarmasin. This research uses quantitative descriptive method. A research sample of 125 people was chosen randomly from 181 lecturers at the Tarbiyah and Teacher Training Faculty of UIN Banjarmasin. The data collection was done using a valid and reliable questionnaire and analyzed using Path Analysis technique. The results show: (1) transformational leadership, work discipline, and job satisfaction have a direct correlation to the lecturers' performance; and (2) It also confirms that there is an indirect effect of the transformational leadership and work discipline through job satisfaction on the lecturers' performance at the Faculty of Tarbiyah and Teacher Training at UIN Antasari Banjarmasin. This study concludes that different results obtained in terms of influence and significance and for the independent variables studied.
\end{abstract}

Keywords: Transformational leadership, work discipline, job satisfaction, teacher performance

\section{Introduction}

The quality of an educator is the main thing in achieving the success of an educational process. That is because everything that is done by an educator will affect student achievement academically and non-academically (Blazar \& Kraft, 2017; Mahler, Großschedl, \& Harms, 2018). Besides, how to communicate educators will also affect the character of students (Darling-Hammond, 2000). In other words, the quality of educators dramatically influences the quality and learning outcomes. It is said that the better the quality of educators, the better the quality of learning and student achievement (Poernamawijaya, Sulaiman, Suriansyah, \& Dalle, 2018). Furthermore, educators' quality will also be reflected in the performance of these educators because performance includes behavior based on knowledge, expertise, and ability to adapt (Pradhan \& Jena, 2017).

Because of this, it can be said that the performance of educators automatically has a crucial position in shaping the eminence of an educational institution. The existence of educators who have excellent performance makes it easier for educational institutions to produce quality graduates and achieve targeted missions (Belsito, 2016). Thus, improving the performance of teaching staff will make the quality of learning better and improve student outcomes (Mahgoub \& Elyas, 2014; Dewi \& Djohar, 2018).

Theoretically, the performance of a worker is influenced by various factors. These factors

\section{How to cite:}

Sihombing, M. (2020). The effect of transformational leadership, work discipline, and job satisfaction on lecturers' performance at the Tarbiyah and Teachinf Faculty of UIN Antasari Banjarmasin. Journal of K6, Education, and Management, 3 (2), 100- 108. doi: 10.11594/jk6em.03.02.01 
include leadership patterns, job satisfaction, and work discipline. In the business world, leadership patterns are vital in achieving the vision and mission or success of an organization (Patiara \& Wang, 2020). The same applies to the world of education, where the principal's leadership dramatically influences the success of a school (Wills, 2016; Aslamiah \& Saleh, 2019). More specifically, a leader's leadership style will also change the sustainability of the success achieved by an institution (Pantouvakisa \& Vlachos, 2020). That is because the pattern of leadership will shape the work atmosphere or work environment (Mulyasa, 2012). If a leader can carry out leadership patterns that can form a comfortable and pleasant atmosphere for everyone, then all workers will work well. Vice versa, if the leadership pattern applied by a leader makes the workers uncomfortable, then any work will not be carried out correctly.

According to Suarsana (2009) states that there is a strong relationship between the principal's leadership patterns and the performance of educators. One of the leadership models that are considered per the changes and developments of the times and can increase employee productivity is transformational leadership (Bass \& Riggio, 2006).

Transformational leadership models can inspire and encourage workers' creativity and motivation to work better in achieving institutional goals. Besides, the transformational leadership model also increases workers' trust in leaders Also workers willing to accept change as an effort to improve (Yue, Men, \& Ferguson, 2019). That is because workers will feel involved or valued by their leaders. When they feel that they are valued they will have a greater effort to make the organization achieve a better performance by working harder. It is because, transformational leadership patterns provide opportunities for all employees to contribute optimally without differentiating their status, race, and background in understanding and achieving a shared vision (Mohammad, ALZeaud, \& Batayneh, 2011). By feeling valued and given clear responsibilities, workers will be motivated to work better to achieve the set work targets and become more creative and have a good initiative to do their job without waiting for the leader to remind them about their duties. Another factor that also influences performance is job satisfaction. According to Handoko (2012) job satisfaction has something to do with emotional state that the employees have in viewing their work. Therefore, someone's perception on job satisfaction can be assessed from a group point of view or individual point of view (Saks, 2002). In addition, when workers have a sense of job satisfaction, they will love their work always to carry out their work optimally and adequately. Those who love their job will have a good commitment to help their company in achieving its goals (Rajak \& Pandey, 2017; Mathur \& Salunke, 2013). It can be said that job satisfaction would make workers more enthusiastic about working because they feel comfortable in doing their job and set their own goals to be achieved.

Besides job satisfaction, another factor that can affect performance is work discipline. Work discipline can be seen from the employees' attitude that shows obedience, respect, and obey the rules that apply in writing or not and can implement it and do not avoid receiving the penalties (Ardana, 2012). Sagala (2013) also states that employees who have high work discipline are consistent, consistent, consistent with the principle, and responsible for the tasks given to them.

Seeing the importance of the performance of an educator on the quality of education, the researcher wants to identify how transformational leadership patterns, job satisfaction, and work discipline influence the performance of lecturers at the Faculty of Tarbiyah and Teacher Training of UIN Antasari Banjarmasin. Hopefully, this study can be a reference optimizing the factors that positively affect lecturers' performance to realize a better quality of education in the Faculty of Tarbiyah and Teacher Training of UIN Antasari Banjarmasin.

\section{Material and Methods}

The study population was 181 lecturers from the Tarbiyah and Teaching Faculty of UIN Banjarmasin. Based on Slovin's criteria, the were 125 lecturers taken as the samples of this study. Those 125 lecturers was selected by proportional stratified random sampling. This 
study collected the data needed using a Likert scale questionnaire with a score of 1 to 5 , which tested validity and reliability. There are four questionnaires to collect the data. They are the questionnaires to measure the: (a) transformational leadership, (b) the work discipline, (c) the job satisfaction, and (d) lecturer performance questionnaire.

To analyze the data of the study, the researcher applied path analysis. The hypotheses of the study are $\mathrm{H}_{1}$ : there is an impact of the implementation of transformational leadership on lecturers' performance. $\mathrm{H}_{2}$ : there is an influence of job satisfaction on lecturer performance. $\mathrm{H}_{3}$ : there is an influence of work discipline on lecturer performance. $\mathrm{H}_{4}$ : there is transformational leadership's influence on job satisfaction. $\mathrm{H}_{5}$ : there is an influence of work discipline on job satisfaction. $\mathrm{H}_{6}$ : there is an indirect effect of transformational leadership on the performance of lecturers through job satisfaction. $\mathrm{H}_{7}$ : There is an indirect effect of work discipline on lecturers' performance through work decisions.

\section{Results and Discussion}

Based on the analysis that has been conducted by the researcher. The results of the path analysis to answer each hypothesis in this study can be seen in Table 1 and Table 2 . The result of the analysis on those two tables are the summary of the statistical analysis using SPSS for windows.

Table 1. Results of Path Analysis in Structure Model 1

Structural 1 Transformational Leadership, Work Discipline Against Job Satisfaction

\begin{tabular}{llcc}
\hline Variable & Path coefficient & T & Sig \\
\hline Transformational Leadership & 0,129 & 2.216 & 0,029 \\
\hline Work Discipline & 0,335 & 3,266 & 0,001 \\
\hline
\end{tabular}

Table 2. Results of Path Analysis in Structure Model 2

Structural 2 Transformational Leadership, Work Discipline, and Job Satisfaction with Lecturer Performance

\begin{tabular}{llll}
\hline Variable & Path coefficient & $\boldsymbol{t}$ & Sig \\
\hline Transformational Leadership & 0,077 & 0,550 & 0,583 \\
\hline Work Discipline & 0,418 & 2,909 & 0,004 \\
\hline Job satisfaction & 0,020 & 0,191 & 0,849 \\
\hline
\end{tabular}

Table 3. Summary of Hypothesis Testing $\mathrm{H}_{1}, \mathrm{H}_{2}, \mathrm{H}_{3}, \mathrm{H}_{4}$, and $\mathrm{H}_{5}$ Hypotheses

\begin{tabular}{lll}
\hline Hypothesis & Sig & Decision \\
\hline $\begin{array}{l}\mathrm{H}_{1}: \text { There is an influence of transformational leadership on } \\
\text { lecturer performance }\end{array}$ & 0,583 & Received \\
\hline $\begin{array}{l}\mathrm{H}_{2}: \text { There is an influence of work discipline on lecturer } \\
\text { performance }\end{array}$ & 0,004 & Received \\
\hline $\begin{array}{l}\mathrm{H}_{3}: \text { There is an influence of job satisfaction on lecturer } \\
\text { performance }\end{array}$ & 0,849 & Received \\
\hline $\begin{array}{l}\mathrm{H}_{4}: \text { There is an influence of transformational leadership on job } \\
\text { satisfaction }\end{array}$ & 0,029 & Received \\
\hline $\mathrm{H}_{5}:$ There is an influence of work discipline on job satisfaction & 0,001 & Received \\
\hline
\end{tabular}

Table 4. Summary of $\mathrm{H}_{6}$ and $\mathrm{H}_{7}$ Hypothesis Testing Decisions

\begin{tabular}{llll}
\hline \multirow{2}{*}{ Hypothesis } & \multicolumn{2}{l}{ Path coefficient } & \multirow{2}{*}{ Decision } \\
\cline { 2 - 3 } & Direct & No Direct & \\
\hline $\begin{array}{l}\text { H6: There is an indirect effect of transformational } \\
\text { leadership on lecturer performance through job }\end{array}$ & & & \\
satisfaction & 0,202 & 0,037 & Received \\
to be continued.......... & & \\
\hline
\end{tabular}




\begin{tabular}{llll}
\hline \multirow{2}{*}{ Hypothesis } & \multicolumn{2}{l}{ Path coefficient } & \multirow{2}{*}{ Decision } \\
\cline { 2 - 3 } & Direct & No Direct & \\
\hline $\begin{array}{l}\text { H7: There is an indirect effect of work discipline } \\
\text { on lecturer performance through job satisfaction }\end{array}$ & 0,364 & 0,018 & Received \\
\hline
\end{tabular}

The effect of transformational leadership, work discipline, and job satisfaction on lecturer performance

This study found that there is an influence of Transformational Leadership on the Performance of Lecturers in the Faculty of Tarbiyah and Teacher Training of UIN Antasari Banjarmasin. However, the effect of the statistical test results was declared not significant. Thus, this finding differs from the conclusions of the research results from previous researchers who conducted studies to determine the effect of transformational leadership on performance.

Empirically, several previous studies have found that transformational leadership has a positive and significant direct effect on workers' performance. For example, research conducted by Jyoti \& Bhau (2015) found that through the distribution of authority on the implementation of transformational leadership, the performance of lecturers in several universities in the Jammu and Kasmir region of India was better. The results of the study are also confirmed by the results of research Kusumayani, Natajaya, \& Atmadja (2013) which also states that there are positive and significant contributions between leaders' behavior on the performance of educators. A study conducted by Saragih (2007) found that teachers also argued that principals' leadership greatly influenced their desire to carry out their work correctly or vice versa.

According to Humphreys (2005), a leader whose transformational leadership style will cause a constant change in the direction of improvement for the organization. That is because transformational leadership can make employees more innovative (Carreiro \& Oliveira, 2019). The innovation arises because of the freedom and trust given to employees to be creative.

Besides, the implementation of transformational leadership in educational institutions has also proven capable of making healthy organizations (Toprak, Inandi, \& Colak, 2015). Applying all employees as work partners to make everyone feel valued makes the organizational atmosphere comfortable for everyone. No employee feels excluded or ignored. With this spirit of willingness, the organization becomes better, and because of stronger emotional ties (Mulyasa E. , 2004).

Likewise, the culture created in the school environment will also be better and collaborative with the implementation of transformational leadership (Ngang, 2011). A culture of mutual respect and respect will be created and realized. The culture of being responsible for work will increase because of the giving of trust and respect for all people. Communication will also be better because there is not too much distance between leaders and subordinates (Simanjuntak, 2005). So, if a problem occurs, then the information can be immediately identified, and the solution sought together.

In terms of work discipline, this study found that Work Discipline affects Lecturers' Performance positively. The result of this research is similar to the analysis result of Hidayati, Perizade, \& Widiyanti (2019). Their study confirms a robust relationship of work discipline and employee performance. People who have excellent work discipline tend to love their work. Thus, those who love their work will always be the best in everything they do.

Similar results were also found by Thaief, Baharuddin, Priyono, \& Idrus (2015), who found that work discipline, especially in time discipline, significantly affects employee performance. Those who value time will always try not to waste time doing their best work in the most efficient time possible. It means that those who value time will always try to use the time for useful things. If at work, then they will focus on spending their time thoroughly to do their job. In other words, the more disciplined an employee is, the higher their performance.

According to Liden (2001), enforcement of work discipline can overcome poor work problems and strengthen employee work behavior in one group or organization. If discipline can be implemented well and does not delay time, 
then problems in performance will not likely be worse. That is because if every employee has high discipline, every issue that occurs can be resolved quickly and easily.

Besides, employees' ability to manage time and work according to priority scale will make employee performance better. Furthermore, time planning and attitude towards time also determine the performance of an employee. Thus, the better their plan and approach towards time, the better their performance (Abduljabbr, Mahdi, \& Almsafir, 2012). Workers who do not have proper planning will often forget important things. Therefore, they will often face problems in the implementation of work.

Moreover, employees who do not value time will often be late to do their work, and their work results also tend to be not optimal. Most people who cannot appreciate time will spend their time on unproductive rights, and finally only do their job when the deadline is almost over in a hurry. With the work that is less than the maximum, the output produced by these workers also becomes not optimal.

In terms of job satisfaction, an insignificant effect was identified between Job Satisfaction and the Lecturers Performance was found at the Faculty of Tarbiyah and Teacher Training of UIN Antasari Banjarmasin. Compared with previous studies, there is a slightly different result from the previous research findings. The conclusions of previous studies stated that job satisfaction affects employees' performance positively and significantly.

Neither is the case in the business world. Roberts \& David (2020) also found that employee job satisfaction affects the employees' performance significantly. Thus, employees who have higher job satisfaction tend to have better performance (Kelimeda, Hairudinor, Ridwan, \& Dalle, 2018). Thus, in one hand, someone dissatisfied with the position will showsa negative attitude towards the work performed, while those with positive attitude will be able to face challenges and problems better to achieve the organization's vision.

From the results of direct analysis of the relationship between each independent variable (transformational leadership, work discipline, and job satisfaction) with the dependent variable (lecturer performance) in this study, it can be said that all independent variables directly influence the dependent variable. However, for transformational leadership and job satisfaction, this study found that the effect was not significant on the performance of lecturers at the Faculty of Tarbiyah and Teacher Training of UIN Antasari Banjarmasin.

\section{The effect of transformational leadership, and work discipline on job satisfaction}

The result of the analysis proves that a crucial effect of Transformational Leadership exists on Job Satisfaction at the Faculty of Tarbiyah and Teacher Training of UIN Antasari Banjarmasin. That finding is confirmed by the study by Kouni, Koutsoukos, \& Panta (2018), who also found that there is a robust effect of transformational leadership of the headmaster on the teachers' job satisfaction in Greece. Likewise, the results of the study conducted by Haddad, Badran, \& Daood (2018) found the same results namely, transformational leadership influences the staffs' satisfaction on their job.

Transformational leadership has a strong influence on job satisfaction based on several reasons. One reason is that the implementation of transformational leadership can create a better working atmosphere so that employees feel comfortable and have a positive attitude to the work environment (Belias \& Koustelios, 2014). Besides, the distribution of authority and giving trust from leaders to subordinates makes subordinates become more valued so that they are more enthusiastic about working even to achieve results that are more than the target set (Hanaysha, et al., 2012).

It also proves that Work Discipline has substantial impact on Job Satisfaction at the Tarbiyah and Teaching Faculty of UIN Antasari Banjarmasin. According to Ghozali (2009), job satisfaction is a manifestation of employees' attitude with sincerity and a sense of awareness in obeying company regulations and policies to achieve company goals. A work discipline is a form of job satisfaction because people who are satisfied with what is done will 
tend to love their work and always try to do their best.

When a person is satisfied in carrying out the work, of course, he will try to maximize the capabilities possessed in the completion of their duties. That is, they will always try to improve the quality of themselves to provide the best results. If someone can produce maximum work, then he will have pride in what is done. This pride will then be a motivation for these workers to always work for a maximum result.

\section{The effect of transformational leadership on performance through job satisfaction}

The results of the intervening or mediation assessment show that Transformational Leadership affects Lecturer Performance of 0.202 . While the indirect effect through Job Satisfaction is $0.557 \times 0.068=0.037$. The calculation results show that Transformational Leadership affects Lecturer Performance greater than the value of the indirect effect through Job Satisfaction. With these results, in other words Job Satisfaction cannot be a variable mediating the Influence of Transformational Leadership toward the the lecturers' Performance.

These findings are supported by Ivansyah's research (2019), which proves that the transformational and transactional leadership styles have a positive and significant effect on employee satisfaction. Similarly, transformational and transactional leadership styles affect the employees' performance positively. Furthermore, job satisfaction also positively and significantly affects employees' performance, as well. Those variables have a considerable influence indirectly on employee performance through satisfaction.

\section{The effect of work discipline on performance through job satisfaction}

Based on the results of the intervening or mediation test shows the effect of Work Discipline on Lecturer Performance of 0.364 . While the indirect effect through Job Satisfaction is $0.584 \mathrm{X}-0.032=-0.018$. The calculation results show that the value of the direct influence of Work Discipline on Lecturer Performance is greater than the value of the indirect effect through Job Satisfaction. With these results, it can be concluded that Job Satisfaction is not able to be a variable that mediates the influence between Work Discipline on Lecturer Performance. Cahya's study (2019) supports this study. He found a strong and substantial effect of work discipline on performance both directly and indirectly through job satisfaction. Those who are discipline normally will work harder and can manager their works better than those who are less discipline. Thus, it can be a strong indicator of a good employee. Since discipline is a part of culture, this positive attitude should be practiced by all of the member of the organization continuously.

\section{Conclusion and Recommendation}

From the results of the analysis conducted, it can be concluded that: 1) there is a transformational leadership influence on lecturer performance; 2) there is an influence of job satisfaction on lecturer performance; 3 ) there is the influence of work discipline on lecturer performance; 4) there is a transformational leadership influence on job satisfaction; 5) there is an influence of work discipline on job satisfaction; 6) there is an indirect effect of transformational leadership on lecturer performance through job satisfaction; 7) there is an indirect effect of work discipline on lecturer performance through job satisfaction. This study shows that transformational leadership, work discipline, and job satisfaction directly affect performance. Also, job satisfaction cannot be a variable that mediates transformational leadership and work discipline to affect the performance of lecturers at the Faculty of Tarbiyah and Teacher Training of UIN Banjarmasin.

Furthermore, although transformational leadership, work discipline, and job satisfaction were found to directly affect the performance of lecturers at the Faculty of Tarbiyah and Teacher Training at UIN Banjarmasin, not all of these effects proved to be significant.

Compared with the results of previous studies, the results are different from earlier studies, which stated that both transformational leadership and job satisfaction have a significant effect on the performance of employees and educators. 
Based on the different research results, it is necessary to conduct further studies on the reasons that make transformational leadership and job satisfaction of lecturers at the Faculty of Tarbiyah and Teacher Training of UIN Banjarmasin did not have a significant effect on lecturer performance. By carrying out this research, problems encountered were found in the implementation of transformational leadership and job satisfaction of lecturers, making the impact not optimal. These reasons can later be used as sources of information to increase the transformational leadership influence and job satisfaction.

Furthermore, if the problem is found, steps to improve transformational leadership and job satisfaction of lecturers can be done better. It is essential to consider the improvement will affect the performance of lecturers, which will affect the quality of the implementation of education in the Faculty of Tarbiyah and Teacher Training of UIN Banjarmasin. Besides, given that lecturer performance is also influenced by other factors beyond the three factors examined in this study, subsequent studies also need to be tested on other factors that also contribute to lecturer performance at the Faculty of Tarbiyah and Teacher Training UIN Banjarmasin.

With the identification of more and more factors that affect lecturers' performance, the institution can develop strategies to strengthen the elements that have proven to influence lecturer performance significantly. Thus, the institution can realize the improvement of lecturer performance as expected while enhancing the quality of learning at the Tarbiyah and Teacher Training Faculty of UIN Banjarmasin. If the lecturers' quality improve, it means the quality of the students and the faculty will increase automatically. In addition, if the Tarbiyah and Teacher Training Faculty of UIN Banjarmasin the other faculties also may do the same thing in order to produce a good quality of education.

\section{Acknowledgment}

Our gratitude and appreciation extend to all parties involved and contributed in completing this research.

\section{References}

Abduljabbr, A. N., Mahdi, O. R., \& Almsafir, M. K. (2012). Relationship between time management and job performance empirical study in Malaysia Privet University. Journal of Advanced Social Research, 2(10), 427-438.

Ardana. (2012). Human Resource Management. Yogyakarta: Graha Ilmu.

Aslamiah, H. P., \& Saleh, M. (2019). Contribution of Principal Transformational Leadership, Work Motivation, Through Satisfaction with OCB Teachers. Journal of K6, Education, and Management (j-K6EM).

Bass, B. M., \& Riggio, R. E. (2006). Transformational leadership, Second edition. New Jersey: Lawrence Erlbaum Associates, Publishers.

Belias, D., \& Koustelios, A. (2014). Transformational leadership and job satisfaction in the banking sector: A review. International Review of Management and Marketing, 4(3), 187-200.

Belsito, C. (2016). The importance of 'teacher quality' and 'quality teaching' on academic performance. Journal of Student Engagement: Education matters, 6(1), 28-38. Retrieved from t:http://ro.uow.edu.au/jseem/vol6/iss1/5.

Blazar, D., \& Kraft, M. A. (2017). Teacher and teaching effects on students' attitudes and behaviors. Educational Evaluation and Policy Analysis, 146-170.

Cahya, P. T. (2019). The Effect of Work Discipline and Workload on Performance through Job Satisfaction in Teachers at SD Muhammadiyah 1 Krian. Surabaya: Thesis. Universitas Airlangga.

Carreiro, H., \& Oliveira, T. (2019). Impact of transformational leadership on the diffusion of innovation in firms: Application to mobile cloud computing. Asia Pacific Management Review, 107, 104-113. doi:https://doi.org/10.1016/j.compind.2019.02.006

Darling-Hammond, L. (2000). Teacher quality and student achievement: A review of state policy evidence. Education Policy Analysis Archives, 8(1), 1-44.

Dewi, L. P., \& Djohar, A. (2018). The effect of teacher performance in implementation of the 2013 curriculum toward chemistry learning achievement. IOP Conf. Series: Materials Science and Engineering, 335, 1-5. doi:10.1088/1757899X/335/1/012129.

Ghozali, I. (2009). Multivariate Analysis Application with SPSS Program. Semarang: Diponegoro University.

Haddad, S., Badran, 0., \& Daood, A. (2018). The impact of transformational leadership style on employees' job satisfaction. International Journal of Pure and Applied Mathematics, 119(18), 887-900.

Hanaysha, J. R., Khalid, K., Mat, N. K., Sarassina, F., Rahman, M. Y., \& Zakaria, A. S. (2012). Transformational leadership and 
job satisfaction. American Journal of Economics, 2, 145-148. doi:10.5923/j.economics.20120001.32

Handoko, T. H. (2012). Personnel Management and Human Resources. Yogyakarta: BPFE.

Hidayati, S. K., Perizade, B., \& Widiyanti, M. (2019). Effect of work discipline and work environment to performance of employees. International Journal of Scientific and Research Publications, 9(12), 391-398. doi:http://dx.doi.org/10.29322/IJSRP.9.12.2019.p9643

Ivansyah, H. N. (2019). The influence of transformational and transactional leadership styles on employee performance with satisfaction as an intervening variable on PT Tunas Subur Utama Pacitan employees. Yogyakarta: Indonesian Islamic University.

Jyoti, J., \& Bhau, S. (2015). Transformational leadership and job performance: A study of higher education. Journal of Services Research, 15(2), 1-36.

Kelimeda, Hairudinor, Ridwan, M. N., \& Dalle, J. (2018). The effect of motivation, job satisfaction and job discipline toward employee performance of PT. Buma Perindahindo At Lng Tangguh Site, Teluk Bintuni Regency, West Papua, Indonesia. European Journal of Human Resource Management $\quad$ Studies, 2(1), 49-73. doi:10.5281/zenodo.2040456

Kouni, Z., Koutsoukos, M., \& Panta, D. (2018). Transformational leadership and job satisfaction: the case of secondary education teachers in Greece. Journal of Education and Training Studies, 6(10), 158-168. doi:10.11114/jets.v6i10.3451.

Kusumayani, A., Natajaya, N., \& Atmadja, B. (2013). Contribution of principal's leadership behavior, teacher job satisfaction, and teacher's work commitment to the performance of state high school teachers in Amlapura City. E-Journal Postgraduate Program Ganesha University of Education , 18.

Liden, R. C. (2001). Managing Individual Perormance in Work Groups. Journal Human Resource Management, 40(1), 6372.

Mahgoub, Y. M., \& Elyas, S. A. (2014). Development of teacher performance and its impact on enhancing the quality of the educational process. Pensee Journal, 76(2), 169-179.

Mahler, D., Großschedl, J., \& Harms, U. (2018). Does motivation matter? - The relationship between teachers' self-efficacy and enthusiasm and students' performance. Plos One 13(11), e0207252. doi:https://doi.org/10.1371/journal.pone.0207252.

Mathur, G., \& Salunke, M. (2013). Organizational commitment and job satisfaction: A study of manufacturing sector. APOTHEOSIS: Tirpude's National Journal of Business Research, 4(1), 129-143.
Mohammad, S. I., AL-Zeaud, H. A., \& Batayneh, A. M. (2011). The relationship between transformational leadership and employees' satisfaction at Jordanian private hospitals. Business and Economic Horizons, 5(2), 35-46.

Mulyasa. (2012). Principal's management and leadership. Jakarta: Bumi Aksara.

Mulyasa, E. (2004). School based management. Bandung: PT. Remaja Rosdakarya.

Ngang, T. K. (2011). The effect of transformational leadership on school culture in male' primary schools maldives. Procedia - Social and Behavioral Sciences, 2575-2580.

Pantouvakisa, A., \& Vlachos, I. (2020). Talent and leadership effects on sustainable performance in the maritime industry. Transportation Research Part D: Transport and Environment, 86, 1-12. doi:https://doi.org/10.1016/j.trd.2020.102440

Patiara, A., \& Wang, Y. (2020). Managers' leadership, compensation and benefits, and departments' performance: Evidence from upscale hotels in Australia. Journal of Hospitality and Tourism Management, 42, 29-39. doi:https://doi.org/10.1016/j.jhtm.2019.11.005

Poernamawijaya, L. W., Sulaiman, S., Suriansyah, A., \& Dalle, J. (2018). Contribution on supervision of supervisor, principals motivation, kindergarten teacher performance to improving the kindergarten quality in West Banjarmasin, Indonesia. European Journal of Alternative Education Studies(3), 130-146. doi:10.5281/zenodo.2261031.

Pradhan, R. K., \& Jena, L. K. (2017). Employee performance at workplace: Conceptual model and empirical validation. Business Perspectives and Research, 5(1), 1-17. doi:10.1177/2278533716671630.

Rajak, B., \& Pandey, M. (2017). Exploring the relationship between job commitmentand job satisfaction through a review of literature. Management Insight, 13(1), 74-79. doi:https://doi.org/10.21844/mijia.v13i01.8363.

Roberts, J. A., \& David, M. E. (2020). Boss phubbing, trust, job satisfaction and employee performance. Personality and Individual Differences, 1-10. doi:https://doi.org/10.1016/j.paid.2019.109702.

Sagala, R. \&. (2013). Human resource management for companies. Jakarta: Rajawali Pers.

Saragih, J. R. (2007). Perceptions of BPK Penabur Jakarta senior high school teachers on leadership, communication and cooperation. Jurnal Pendididkan Penabur, 9(12), 1-13.

Simanjuntak, P. J. (2005). Work management and evaluation. Jakarta: University of Indonesia Faculty of Economics Publisher Institute.

Suarsana, I. K. (2009). Contribution of school principals' leadership behavior, teacher's work spirit towards improving the 
performance of state high school teachers in Gianyar district. Singaraja: Ganesha University of Education.

Thaief, I., Baharuddin, A., Priyono, \& Idrus, M. S. (2015). Effect of training, compensation and work discipline against employee job performance. Review of European Studies, 7(11), 23-33. doi:10.5539/res.v7n11p23.

Toprak, M., Inandi, B., \& Colak, A. L. (2015). Do leadership styles influence organizational health? a study in educational organizations. International Journal of Educational Methodology, 1(1), 19-25. doi:10.12973/ijem.1.1.19.
Wills, G. (2016). Principal leadership changes and their consequences for school performance in South Africa. International Journal of Educational Development, 51, 108124. doi:https://doi.org/10.1016/j.ijedudev.2016.08.005.

Yue, C. A., Men, L. R., \& Ferguson, M. A. (2019). Bridging transformational leadership, transparent communication, and employee openness to change: The mediating role of trust. Public Relations Review, 45(3), 1-13. doi:https://doi.org/10.1016/j.pubrev.2019.04.012. 